\title{
THE NEW ELEMENTS OF MATHEMATICS
}




LiNITE sTATFS CONST SUKVEY.

\section{A QUINCUNCIAL PROJECTION OF THE WORLD}

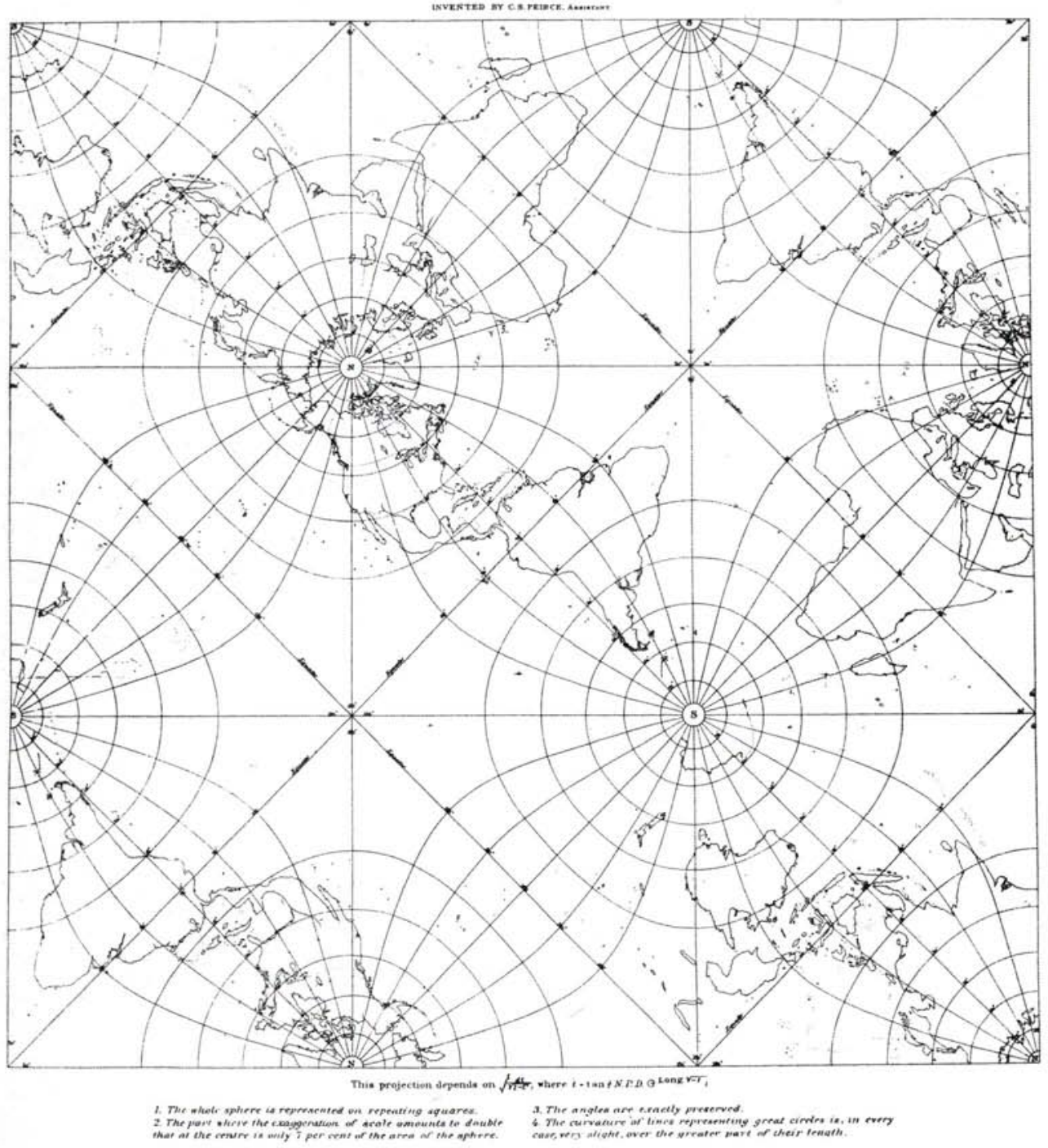

The Quincuncial Map Projection invented by C. S. Peirce in 1876.

(From the Charles S. Peirce Collection in the Houghton Library, Harvard University.) 


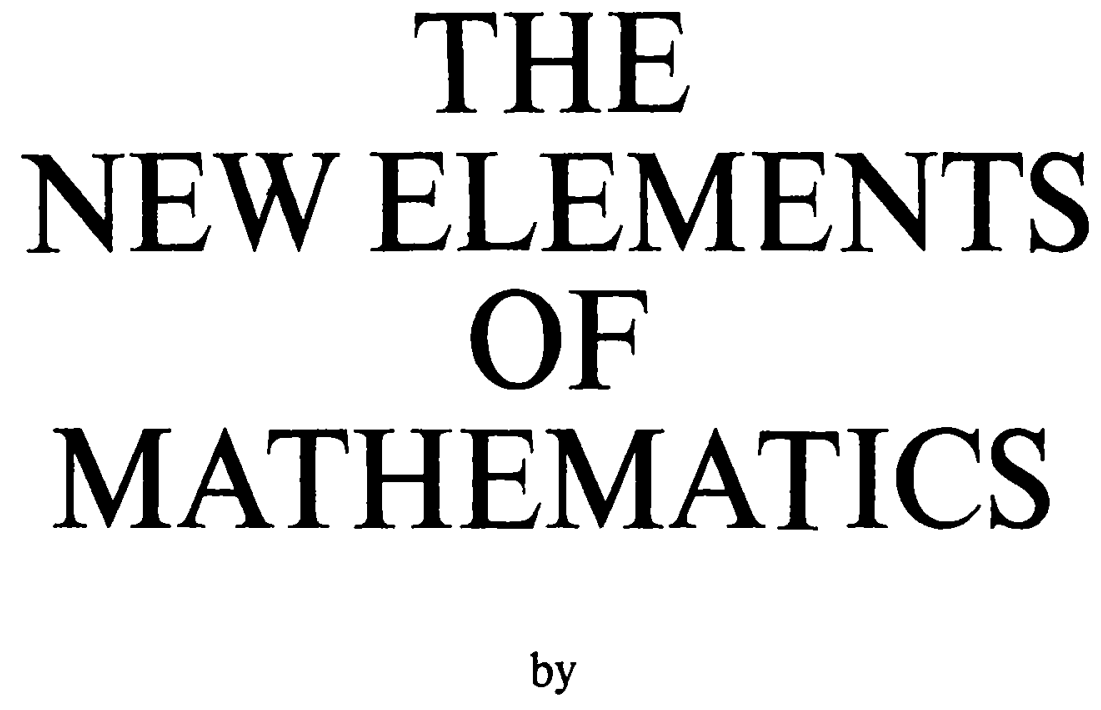

\title{
CHARLES S. PEIRCE
}

\author{
Edited by \\ CAROLYN EISELE \\ VOLUME III/1 \\ MATHEMATICAL MISCELLANEA
}

1976

$\mathbf{m}$ 
(C) Copyright 1976

Mouton \& Co. B.V., Publishers, The Hague

No part of this book may be translated or reproduced in any form, by print, photoprint, microfilm, or any other means, without written permission from the publishers.

\section{ISBN 902793035 X}

American edition published by Humanities Press Inc. - Atlantic Highlands, N.J.

\section{Library of Congress Cataloging in Publication Data}

Peirce, Charles S.

Mathematical Miscellanea.

(His The new elements of mathematics; v. 3)

Includes index.

1. Mathematical Miscellanea. I. Title.

QA39.2.P42 vol. 3 [QA531] 510'.8s [516'.24] 76-15328

ISBN 0-391-00641-X 